\title{
A study to assess the effectiveness of mind mapping technique vs lecture method regarding psychological test on knowledge among nursing students at St. James College of Nursing, Chalakudy
}

Antony $\mathrm{C}^{*}$

\section{*Corresponding author:}

Ms. Christy Antony, M.Sc. Nursing Community Health Nursing, Asst professor, St. James College of Nursing Chalakudy, Thrissur, Kerala, India

Email: christybenny78@gmail.com ORCID

\section{Information about the article:}

Received: Jan. 17, 2019

Accepted: Feb. 20, 2019

Published online: Dec. 27, 2019

\section{Publisher}

Nepal Health Research Society, Bahundhara -6, Gokarnesowor Municipality, Kathmandu, Nepal eISSN 2382-5545, ISSN 2676-1343 (Print)

(C) The Author(s). 2019

Content licensing: CC BY 4.0

\section{ABSTRACT}

\section{Background}

Mind maps are highly effective visual aids that enable students to group together different ideas and enable teachers to present ideas visually and assess their students' conceptual development and understanding. The present study was to assess effectiveness of mind mapping technique vs lecture method regarding psychological test on knowledge among nursing students at St. James College of Nursing Chalakudy. The study included 50 first year B.Sc. nursing students, 25 in lecture group and 25 in mind mapping group.

\section{Materials and methods}

A Quasi-experimental non randomized control group design was adopted and nonprobability convenient sampling technique was used to select the samples. Structured teaching programme regarding psychological test was administered on both group and knowledge level of the students was evaluated immediately after the teaching (' 0 day') and $7^{\text {th }}$ day to assess the retention of knowledge. Data collected by using structured questionnaire and analysed by using descriptive and inferential statistics.

\section{Results}

The study revealed that the mean post test knowledge score of students on '0'day in mind mapping group is (13.52) higher than the lecture group (9). The calculated $t$ value (7.66) is higher than the table value (6.06) at 0.05 level of significance. The mean of the post test knowledge of students on $7^{\text {th }}$ day by using mind map score is 13.32 , it is higher than mean of the lecture method knowledge score (8.80). The calculated t value is (7.92) is greater than the table value (2.60) at 0.05 level of significance.

\section{Conclusion}

There for it can be concluded that the mind mapping teaching method is very effective than lecture method among the nursing student on psychological test. The study shows that mind mapping technique help the student to learn, recall, organize and make information meaningful. So they can perform and get good result in examination by using mind mapping technique.

\section{Key words}

Effectiveness, lecture method, mind mapping, psychological test. 